\title{
IDENTITY CONSTRUCTION IN ARMENIAN MUSIC ON THE EXAMPLE OF EARLY FOLKLORE MOVEMENT
}

\author{
Brigitta Davidjants
}

\begin{abstract}
The aim of the article is to present various identity constructions in the early Armenian folklore movement. Armenian identity construction has been affected by various factors, including Armenia being the first country to adopt Christianity, and also the fact that it has a well-integrated diaspora in the West, both of which are used to present the 'Europeanness' of Armenians. Yet Armenia is surrounded by Muslim countries with which it shares many cultural similarities. Armenia has also been involved in various conflicts with its neighbours, starting with the Romans in the first century BC and ending with the Nagorno-Karabakh War between Azerbaijan and Armenia between 1988 and 1994. Due to these processes, the country is trying to distance itself from the East and, instead, belong to the West, and music can be used for the benefit of such identity construction. As an example, the article introduces various approaches to transcriptions of Armenian folk tunes that were made by composer and folklorist Komitas (Soghomon Soghomonian, 1869-1935), and folklorist Arshak Brutyan (1864-1936). Komitas is regarded as the most important figure in Armenian music. While transcribing folk tunes, he relied more on the Western way of thinking by standardising tunes according to the Western music system while Brutyan, on the other hand, tried to find transcription methods that would fit more with Armenian musical culture. Nowadays, unlike Brutyan, Komitas's ideas are still strongly advocated in Armenian academic circles, and he is respected for unifying Armenian music with Western European musical culture.
\end{abstract}

Keywords: cultural boundaries, early folklore movement, folk tune transcriptions, national identity construction

\section{INTRODUCTION}

In this paper, I will concentrate on national identity construction in the Armenian ethnomusicological discourse in light of the work of the composer and folklorist Komitas (Soghomon Soghomonian, 1869-1935), one of the founders of the discourse, and his contemporary, folklorist Arshak Brutyan (1864-1936). I will show how folk music transcriptions reflect different aesthetic preferences and methodological starting points, and how they can be related to national identity 
construction in general, as folk tunes formed in the past as well as today - an important part of creating a homogenous national identity. In describing those processes, I will analyse the same folk tune transcriptions that were carried out both by Komitas and Brutyan. According to my hypothesis, the former adopted his transcriptions according to the expectations of the Western audience, by simplifying the melodic, rhythmic, and metric elements of folk tunes, whilst the latter sought out methods from inside the culture he was researching by trying to mark down every single melodic and rhythmic characteristic in the tunes. The subsequent reception of Komitas and Brutyan by Armenian musicologists over the last hundred years contains a national identity construction that culturally positions Armenians within Europe. Partly due to that, unlike Brutyan, Komitas still maintains an important position in modern Armenian musicology.

Most of the Eastern European nations have created their own schools of national music in the Western tradition and Armenians are no exception. Armenian writing of national history through music writing emerged in the Russian area in the late nineteenth and early twentieth centuries and continued to develop in Soviet Armenia (Pahlevanyan \& Kerovpyan \& Sarkisyan 2001). In the Armenian national discourse, Komitas is considered to be the founder of Armenian national music. He was a composer, folklorist, musicologist, and music teacher at the time of the national awakening at the end of the nineteenth and beginning of the twentieth centuries. His musical activities brought Armenia closer to Europe: as a folklorist he worked towards the research and preservation of Armenian traditional music, while he also used this music according to the conventions of western national-romantic music. The story of Armenian music has presented Komitas almost as a mythical national hero. ${ }^{1}$ Even today he is the symbol of Armenian European cultural identity, although such a self-perception conflicts with regional realities. Armenia is historically divided into eastern and western Armenia. Since the nineteenth century, eastern Armenia was lodged within the Russian empire and now forms the modern Armenian Republic. The western part belonged to the Ottoman Empire and has been absorbed into eastern Turkey. In Armenian culture two branches can be distinguished, eastern and western, and both have their own dialects, culture, etc. (Samuelian et al. 2003: 26). Komitas lived mainly in today's Turkey, and his identity can be tied more to western Armenian traditions.

Brutyan was Komitas's contemporary and, at first sight, certain similarities can be traced between them. They both originated in the western Armenian region (modern north-eastern Turkey), but studied and graduated from the Gevorkian Theological Seminary in Vagharshapat in the east (today's Etchmiadzin), Brutyan in 1882 and Komitas in 1893. As was typical of the era, they 
were engaged in a large number of activities: they were music theorists, folklorists, and teachers, they developed choral singing, etc. For example, Komitas wrote multiple comparative research papers on traditional music, in which he generalised the traditional music of various nations (Geodakyan 1969: 48), while Brutyan compared Western and Armenian notations (Brutyan 1985: 15). Allegedly, Komitas and Brutyan also met at least once - according to Margarit Brutyan, the grand old lady of Armenian musicology and granddaughter of Arshak Brutyan - when Komitas and another composer, Kara-Mourza, arrived in Alexandropol (today's Gyumri) to give concerts. Brutyan worked there as a music teacher and he introduced them to his choirs for four voices (Brutyan 1985: 15-18).

Brutyan offers interesting material for comparison with Komitas. His position in Armenian musical life and in the history of Armenian music is different. Considering Komitas's role in Armenian musical life also as a composer, Brutyan's scope of activities was narrower, which did not bring him such a prominent position. Though highly appreciated by folk musicians and folklorists (Brutyan 1985: 8; Kushnaryov 1958: 5), he did not gain such public attention as Komitas. He has not been that well recognised by later musicologists, and he also did not form a separate school of folklore in Armenia. The reason might also be that he was more local in his activities and stayed mainly in Alexandropol where he is highly appreciated also today, and where a music school has been named after him. The difference between Komitas's and Brutyan's positions in Armenian ethnomusicology was reinforced and confirmed by later Armenian national music history writing, which evaluated Western concert and choral music more highly than folk music in itself, but perhaps also because Brutyan's transcriptions did not correspond to the ruling ideology of Europeanness.

This all makes it harder to explain Brutyan's position in Armenian folklore discourse, which is not ideologically so loaded as Komitas's, yet also carries a certain meaning. Today, his transcriptions are still used for practical purposes: through history, they have been taken as good examples of Armenian folk music and art of ashugh ${ }^{2}$ (Kushnaryov 1958); folk music students use them in their performances (according to my fieldwork at the Yerevan State Conservatory named after Komitas from 2002 to 2011), etc., yet there is no such discourse around him as around Komitas.

Brutyan was slightly older than Komitas and worked simultaneously with him, and yet they represented different musical worlds. When comparing Komitas's and Brutyan's folk tune transcriptions, one can notice a big methodological difference between approaches towards transcriptions. Their transcriptions reflect their different ways of musical thinking: which aspects either of the folklorists have emphasised, or on what they have concentrated while placing 
the musical material into the framework that originated in a culture different to that of Western tonal music. The analysis shows a difference in their cultural background according to which they observed and valued the collected material. This difference can be partially explained by Brutyan's probably unconscious denial of the ruling European identity construction in his folkloristic work. In his contrast, Komitas's ideological nature becomes particularly evident. This is something that has never been called in question in Armenian musicological discourse.

Yet in Armenian ethnomusicology new trends have also emerged since those days that include new transcription techniques. Beginning in the 1960s, more precise transcription methods were developed in Armenia, too, according to developments of ethnomusicology. Armenian musicologists started to use recordings for transcriptions, many additional marks came into use for marking down melody, they started to make textual analysis next to musical analysis, songs were transposed only exceptionally, etc. Those methods are still present in modern Armenian ethnomusicology (Pahlevanyan 2005: 25-30).

In the next chapter, a description is given of the methods being used in the current research, while in the following parts Armenian music is positioned on the boundaries between East and West. The theoretical background of this research is based on the discourses of post-colonial theorists (Homi Bhabha 1994; Benedict Anderson 2006; etc.), musicologists (Andy Nercessian 2000; Philip Bohlman 2001 [1999]; Carl Dahlhaus 1983 [1980]; etc.), and political scientists who have concentrated on Armenian topics (Ronald Grigor Suny 2001; Razmik Panossian 2002; etc.). The last chapter presents some comparative analyses of two folk tunes that were transcribed both by Komitas and Brutyan. The transcriptions are in the archives of the Charents Museum of Literature and Art in Yerevan, Armenia.

\section{METHODOLOGY}

The aim of the present analysis is to describe the different ideologies in early Armenian folklore movement that reflect themselves in approaches chosen for transcribing the same folk melodies. Such differences can result from different, perhaps hidden, unconscious ideologies, and reflect the cultural context of the two folklorist. By and large, the sociocultural model for studying music is used, in which both the research of the cultural context and comparative music analysis are applied.

Transcriptions are seen as cultural texts, and by analysing them and their cultural background I will highlight the common codes, ideologies, and 
discourses. I try to map what can be said about the individuals featured in the texts, and also how the texts are framed and presented. I am interested in which terms are used and what is their symbolic meaning, and what are the assumptions embedded in the musical texts. I will use the answers to the questions to build arguments about those who construct cultural products and wider social and cultural conditions (Davis 2008: 56).

My first step was to examine Komitas' ${ }^{3}$ and Brutyan's ${ }^{4}$ folk tune collections to discover general tendencies in their transcriptions, which would support my comparative analysis of folk tunes. More than a hundred songs by Komitas and the same amount by Brutyan were examined for having a representative sample of the texts that would help to make more extensive conclusions about the transcriptions. In general, the songs shared the same tendencies that characterised the songs chosen for comparative analysis. Transcriptions made by Komitas were generally without embellishments, the rhythmic picture was symmetric and the songs were both metrically and modally adjusted to correspond to the European discourse of folklorism in the late nineteenth and early twentieth centuries. Brutyan's transcriptions, on the other hand, were characterised by a very complicated rhythmic picture, melodies included many embellishments and were not modally so adjusted to European folklorist discourse.

As a background to Komitas's and Arshak Brutyan's folk tune collections, I also analysed other Armenian folk tune collections, to see which parameters other folklorists had concentrated on: metro-rhythmic, tonal, form, etc. ${ }^{5}$ Here I noticed a tendency that earlier transcriptions - until the first half of the twentieth century, for example by Spiridon Melikyan and Mihran Toumajian resembled more, both rhythmically and tonally, Komitas's transcriptions, yet in the second half of the twentieth century - those of Brutyan's. The latter was common, for example, to an important modern source, the prominent folk tune collection Talin: Zhoghourdakan yergery ${ }^{6}$, which was published in 1984. Rhythmical similarities became especially clear while comparing transcriptions of the same song, such as Le le yaman, by Brutyan and Komitas, and a version of Dle Yaman in Talin, although the latter was created around half a century later (Pahlevanyan 1984: 143-145).

To better understand Armenian folk tunes, I also transcribed and analysed living and recorded performances of folk tunes, to start with Hayrik Muradyan's recordings from 1958 to $1988,{ }^{7}$ and to end with Margarit Voskanyan's performances in 2013. ${ }^{8}$ The analysis was also supported with my own experience of performing Armenian music, and studying, living, and working in Armenia for more than ten years. As experience is central to cultural studies (Pickering 2008: 17), my own practical experience has offered me valuable insight into the performance of Armenian folk music. In other words, my own ethnographic 
observation has been useful as it has offered me an opportunity to document the actual processes and people involved in cultural production (Davis 2008: 58).

The majority of work was done in the archives of the Charents Museum of Literature and Art, with Komitas's archived materials (Archive collections Nos. 302, 303, and 304), and also those of Brutyan's (Archive collections Nos. 3 , 4 , and 5), searching for transcriptions of the same tunes that were made by both of them. I found four songs in which the musical material and lyrics largely overlapped, and compared their tonal, rhythmic, and formal structures, in addition to a few dozen songs that overlapped only to some extent. In the article, I will present the analysis of two of them, Chem chem and Le le yaman, which are both good examples of different approaches to interpreting folk tunes. For both songs, there is one version by Komitas and two versions by Brutyan, which makes a total of six transcriptions.

There is no information available as to where or when precisely these transcriptions were made. Komitas and Brutyan both lived and worked mainly in western Armenia, i.e. the Ottoman Empire. In general, it is known that all of Komitas's transcriptions were made between 1881 and 1913, mostly in the western Armenian area (Muradyan \& Atayan \& Tatevosyan 1956: 28-31), and some in eastern Armenia, i.e. in the Russian Empire (Shaverdyan 1989: 58). Brutyan started his work in the eastern Armenian area at approximately the same time (1879) (Brutyan 1985: 16).

Transcriptions of the same songs made by different folklorists in dissimilar places at different times may differ from each other due to regional features, variability, incidental deviations, etc. Even so, by juxtaposing the songs, an interesting picture of the transcribers unfolds, which reveals the interests and preferences of the folklorists, and the similarities and differences in their cultural background, the era's research methods, etc. Therefore, the transcriptions of the two songs illustrate more general tendencies that characterise the transcriptions of Komitas and Brutyan but - with the analysis of cultural context - also show how their meanings were produced later on in the Soviet era.

Names of places and people in Armenian are transliterated according to eastern Armenian pronunciation and orthographic rules, except the names of persons who originated from western Armenia, as there are minor differences between the two dialects. 


\section{SOME ASPECTS OF IDENTITY CONSTRUCTION IN ARMENIAN CULTURE}

In Armenian musicological literature, both the reception and transcriptions of Komitas and Brutyan - but also of many other Armenian folklorists - bring us to a larger topic of identity construction for Armenians. Identity is the representation of selected habits that are used for defining one's self to others (Turino 2004: 8), and there is an "atavistic belief that identities can be maintained and secured only by eliminating difference and otherness" (Wodak et al. 1999: 3). In Armenian culture, across the centuries, self-positioning towards the West has been common, which often includes creating boundaries and neglecting common ground with regional neighbours. Boundaries can be defined in several ways: geographically, culturally, politically, religiously, linguistically, etc. Armenians locate themselves geographically on the borderlands of East and West; they position themselves geographically in Asia, but as Christians they see themselves as a part of Europe. An essential element of their identity is antagonism towards pre-Russian colonisers who were mostly Muslims. Also today, Armenia is surrounded on three sides by Muslim countries: Azerbaijan, Turkey, and Iran. The idea of Europeanness is reflected in many fields, such as everyday politics and media, as well as arts and humanities. ${ }^{9}$ As one of the reformers of Armenian music according to the Western tradition, Komitas agrees well with the construction of cultural boundaries between Armenia and its Muslim neighbours.

The first important strategy for constructing Europeanness in Armenian identity is related to the adoption of Christianity in the fourth century after Christ (Panossian 2002: 126). Religion is a significant factor in Armenian identity construction. In the South Caucasus, before the Bolshevist Revolution in 1917, identity was shared primarily with co-religionists, rather than with a theoretically bounded territory as a homeland (Suny 2001: 873). In Armenia, Christianity is traced back to the missions of apostles Bartholomew and Thaddeus around AD 60. In AD 301, Saint Gregory the Illuminator converted Armenian king Tiridates III to Christianity, which was soon recognised as the state religion (Ter-Sarkisyants 2005: 136-179). According to legend, Christianity was adopted due to the miraculous convalescence of the king from madness. Yet the reason was probably political: Tiridates III had been informed that Roman Emperor Diocletian had negotiated with the Persian powers (the Sassanids) against the Armenians. As Christians had already been exerting a noticeable influence on Armenian society, the king decided to baptise himself, and Christianity became the official state religion (Panossian 2002: 126). 
Today, Armenians emphasise that they were the first Christian country in the world. They have an independent church, and they are "the defenders of Christianity at the frontiers of Islam" (Suny 2001: 885). The church has been an essential institution in establishing boundaries between Armenians and the 'others'. Particularly, in the diaspora, the church has organised life for centuries; it has been forming the community and preserving it. The church has helped to preserve rituals, foods, dances, and customs, which are all markers of diasporic identity (Yazedjian 2004: 44). The Armenian diaspora emerged first in Middle Eastern countries: during the existence of the Sassanid and Persian empires (Tololyan 2005: 37). The rise of modern diasporas in Western countries is also based on religion: the Armenian genocide of 1915 within the territory of the Ottoman Empire is interpreted in the light of a deep antagonism between Muslim Turks and Christian Armenians. It has to be mentioned that the refugees of the genocide did not form the first wave of the Armenian diaspora: living in diaspora was not new for the Armenians of the twentieth century. Certain waves of emigration can be distinguished in history and the earliest of them go back to the ancient period and the Middle Ages. However, the largest emigration to affect the modern Armenian self-consciousness took place at the beginning of the twentieth century (Adalian 2010: 271).

In the cultural resources of the classical diaspora, suffering experienced through forced exiles, persecutions, and finally genocide, is explained through religious theodicy (Smith 2010: 8). The figure of Komitas is interpreted as being a great example - he was a genocide survivor, and yet surviving is a relative term because after this experience Komitas lost his mind and spent the rest of his life in a nursing home in France (Poladian 1972: 83). According to Shaverdyan, the path trod by "Komitas [---] does not reflect so much, or solely, his personal destiny but rather the nation's" (Shaverdyan 1989: 20). ${ }^{10}$ Also, musicologist Georgi Geodakyan has written the following:

In the destiny of Komitas, on his thorny and tragic path, the whole historical epoch of the Armenian nation is reflected: the rise of national consciousness, struggles, emerging hopes, and the era that concluded with the terrible tragedy of 1915, overshadowed by the most horrible pages in the history of much-affected Armenia. Komitas drank to the bottom the bitter cup of suffering that was devolved to his nation. ${ }^{11}$ (Geodakyan 1969: 7)

So Komitas is included in the genocide discourse. The reception of Komitas reflects how secular nationalists found in ethnohistory resources in the struggle for raising Armenian consciousness and shows that where ethnic heroism is linked to Christian martyrdom, the nation is linked to religion (Smith 2010: 13-14). Komitas has become a martyr, the embodiment of various factors of 
the construction of the Armenian national identity, in which Western culture is contrasted against the Muslim Middle East - such approaches can be traced in most writings about Komitas. ${ }^{12}$ This way, the reception of Komitas shows how music is used in the construction of national ideologies which are especially evident in comparison with other folklorists, i.e. Brutyan in the current case.

\section{ARMENIAN MUSIC IN THE SERVICE OF WESTERN NATIONAL IDEAS}

Western-type Armenian composers appeared in the context of the nineteenthcentury national awakening, when national ideas spread progressively throughout Eastern Europe. The concept of nation was born in an age in which the Enlightenment and Revolution were destroying the legitimacy of the divinelyordained, hierarchical dynastic realm (Anderson 2006: 7), and the idea arose that instead of a dynasty one should be loyal to one's nation. Until the end of the eighteenth century, national style in music was largely a writing convention that a composer could select and change, rather than some inner ethnic character that was inherited at birth (Dahlhaus 1983 [1980]: 90). In the nineteenth century, however, national styles became associated with the ethnic origin.

Armenian musicians were no exception. After 500 years as part of the Persian and Ottoman empires, Eastern Armenia became part of Tsarist Russia (with some areas being taken from Persia in 1828, and others from Turkey in 1878). Armenian societies, cultural and educational centres and publishing houses arose not so much in the areas of modern Armenia, but also in Moscow, Tbilisi, St. Petersburg, Baku, Constantinople, Paris, Venice, Vienna, etc. Constantinople and Tbilisi became the most important centres of Armenian musical culture. Both centres had strong links with European musical culture - Constantinople primarily with France and Italy, while in 1846 Tbilisi itself became a provincial centre within the Russian empire (Pahlevanyan \& Kerovpyan \& Sarkisyan 2001; Samuelian et al. 2003: 26). ${ }^{13}$

Under those conditions, the new generation of Armenian musicians was brought up in the Western tradition and the role of the educated elite was decisive in the rise of nationalist ideas in Armenia. Their relationship to the old Armenian tradition was different. They started to evaluate their ancient culture from the 'outside'. At the same time, in search of musical materials and ideas for new national music it was natural for them to turn to Armenian folklore (Shaverdyan 1989: 40).

This school had nothing in common with earlier Armenian musicians: for centuries musical skills were passed from masters to their apprentices and 
singing was predominantly monodic, but the new musicians were educated in conservatories, and they spread polyphonic choral songs, formed orchestras, organised public concerts, etc. (Geodakyan 1969: 42, 48; Shaverdyan 1989: 47; Brutyan 1985: 15-16). Some younger musicians had studied in Europe, while some were taught by Russian composers who themselves had often received their education in Germany. For example, a composer of choral music, KaraMourza, had studied in Odessa and was one of the first to unify European composition techniques and Armenian folk tunes (Geodakyan 1969: 18). Makar Yekmalyan, who had a strong influence on Komitas, was Rimski-Korsakov's student and was therefore well acquainted with Russian ideas about musical nationalism (Geodakyan 1969: 36; Shaverdyan 1989: 66). Tigran Tchoukhadjian (1837-1898), who composed the first Armenian opera Anush, had studied in Milan; Nikoghayos Tigranyan (1856-1951) in Venice and St. Petersburg, etc. (Geodakyan 1969: 18; Pahlevanyan 2005: 21). Therefore it can be seen that Armenian Western-style interest towards traditional music positions itself towards the Russian sphere of influence, while ideas about collecting and studying folk melodies originate in German comparative musicology of the late nineteenth century.

Among them, Komitas is considered as one of the most important figures. Part of the reason might be that, compared to other early folklorists, he was international and extensive in his activities: he studied musicology in Germany, gave lectures at conferences in France and Turkey, he was member of the International Musical Society, etc. Brutyan, on the other hand, remained, for most of his working career, in Alexandropol. Komitas also travelled around Europe and communicated with European musicologists just at the time when the contemporary music history writing tradition was on the rise. Thanks to this serendipitous timing, Komitas promoted cultural values that later started to re-create his myth in the writings about Armenian history.

After completing his studies at the Gevorkian Theological Seminary in Vagharshapat in 1896, Komitas went to Berlin to study at the Kaiser Friedrich Wilhelm University and at the private conservatory of R. Schmidt. After graduating with a doctorate in musicology, he returned to Vagharshapat where he applied his knowledge to re-organise music studies. He formed an orchestra of western instruments and composed new music for the Armenian liturgy, Patarag (Geodakyan 1969: 48, 42; Shaverdyan 1989:47). Brutyan also received his education at the Theological Seminary in Vagharshapat, and his activities reflect the institutional changes of the period: he formed several schools and church choirs, composed Armenian polyphonic choral songs, and organised public concerts (Brutyan 1985: 15). 
Along with those new ideas, the movement towards collecting folk music developed, and was supported by the belief that the collective national spirit of people is the driving force in history (Dahlhaus 1983 [1980]: 81). Therefore, fieldwork became an important part of the Armenian national movement, and researchers studied their collections with methods acquired from their Western musical education. Transcriptions were based on authentic material, but the scores had to be understandable by the average Western musician or musicologist - those being the addressee of the research and publication. Folk tunes became 'museum pieces', something to conserve, exhibit, and use for composing music in the national style.

The Western audience was important for Komitas, as he had connections with international music institutions. From 1899, he belonged to the International Music Society. In 1906 and 1914 he gave lectures about Armenian traditional and church music at international musicological conferences in Paris (Muradyan \& Atayan \& Tatevosyan 1956: 26-32; Poladian 1972: 83). Also in Paris, he published his arrangements of folk tunes and organised concerts of Armenian music. Komitas also introduced Armenian music to Switzerland, Italy, Russia, etc. (Geodakyan 1969: 95; Shaverdyan 1989: 71). Komitas's own way of thinking was probably nation-centred, as he considered Armenian music to be something special. In an interview to the Armenian newspaper Azatamart in Constantinople, after returning from Paris in 1914, he emphasised that he had succeeded in convincing guests at the conference that Armenian music was of a high artistic value and that "it has been preserved in a more untouchable way than the music of some other nations" (Shaverdyan 1989: 305).

Komitas had also many students and friends who kept alive his memory and continued his school: composers Nikoghayos Tigranyan (1856-1951), Grikor Suni (1876-1939), Armen Tigranyan (1879-1950), Romanos Melikian (1883-1935), Anushavan Ter-Gevondian (1887-1961), Sargis Barkhudaryan (1887-1973), etc. (Muradyan 1960: 273-274), and folklorists Manuk Abegyan (1865-1944), Spiridon Melikyan (1881-1933), Barsegh Kanachian (1888-1967), Mihran Toumajian (1890-1973), and Vagharshak Srvandztian (1891-1958). Those folklorists were also characterised by more normative, European way of transcribing which was typical to the era and to the early folklore movement, and their transcriptions resemble more the transcriptions made by Komitas. ${ }^{14}$

Among Komitas's students, the most important input came from his pupil, musicologist Spiridon Melikyan. He studied under Komitas in Etchmiadzin, Armenian religious centre, and helped him at his work with the choir. Later, in 1904, Melikyan left for Berlin, where he stayed until 1908, to study with the same professors as Komitas. He transcribed folk tune transcriptions of Komitas 
from Armenian notation system, called Limondjian system, into the European one, and prepared the songs for publishing in 1931 (Melikyan 1949: 22-23).

Among Komitas's friends were many Armenian cultural figures who participated actively in creating Armenian national culture, for example poet Hovhannes Tumanyan, together with whom Komitas wanted to write the opera Anush. Another friend of Komitas' was literary scholar Manuk Abeghyan. Together with Komitas, he published in 1903 a collection of folk songs titled One Thousand and One Songs (Shaverdyan 1989: 61-62), which can be seen as an allusion to west and south Asian story compilation One Thousand and One Nights, which became hugely popular in Europe since the Enlightenment era and symbolises Orient.

When it comes to transcribing folk tunes, Armenian early folklorists mostly used their own notational system, one that was comfortable for transcribing monody, but which also carried strong national significance by being derived from the Armenian seventh-century notation, the khaz system. At the beginning of the nineteenth century music theorist Hampartsoum Limondjian (1768-1839) took some symbols from the khaz system and adapted them to the diatonic scale. ${ }^{15}$ The similarity between the new notation and the khaz system was just visual (Kushnaryov 1958: 351-356). In the second half of the nineteenth century, western notation also became widespread, as Limondjian's system was incomplete for writing polyphonic music (Atayan 1973: 168-186). Yet, the system was later used by many folklorists - also by Brutyan and Komitas - for transcribing monodic music. There was also an important ideological aspect concerning Limondjian's system. By the early nineteenth century, the khaz system had reached a crisis point as musicians no longer knew how to read it (Pahlevanyan \& Kerovpyan \& Sarkisyan 2001). By giving the symbols a new meaning, Limondjian hoped to preserve them in the memory of contemporary musicians (Kushnaryov 1958: 351-352). When it comes to the old khaz notation, one more aspect has to be noted. In Armenian musicological literature, it is often claimed that Komitas had almost discovered the key to reading the old khazes, but his work was destroyed in the genocide. ${ }^{16}$ Thanks to this, the claim has become a part of Komitas's reception, in which the genocide is linked to national heroism and martyrdom.

In the nineteenth century, there was a belief all over Europe that national spirit initially revealed itself in folk tunes and would later be embodied in the classical music of this national culture. Creating art music was seen as the aim of collecting and studying folk tunes and a perfect expression of the essential spiritual characteristics of the nation once embedded in folk music (Dahlhaus 1983 [1980]: 62). So, as in many other countries, folk tunes spread into Armenian art music. The intensity of the national message that was com- 
municated by composition was for a long time evaluated by a composer's level of skill in using folk tunes (Nercessian 2000: 85). Armenian composers, such as Kara-Mourza, Makar Yekmalyan, and also Komitas, composed arrangements of Armenian folk tunes (Muradyan 1960: 273-274). In larger choral and polyphonic compositions that required the musical development of folk materials, most composers followed Komitas's principles (ibid.): melody lines and voice parts were created using the modes and rhythmic patterns of a folk tune taken as the thematic material of a new polyphonic composition (Kushnaryov 1958: 599-603). This makes Komitas the key figure among Armenian composers as he laid the foundation for the polyphonic (Western choral) repertoire so that it sounded Armenian and preserved recognisable Armenian tunes (Muradyan 1960: 273-274). At the same time, Brutyan's most valuable achievement was his work as a folklorist; he collected not only Armenian folk tunes but also a wider and more Middle Eastern tradition, the ashugh art (Brutyan 1985: 17).

\section{CERTAIN PECULIARITIES OF ARMENIAN TRADITIONAL MUSIC}

In Armenian traditional music we find peasant folk music with its common genres, such as work songs, ritual songs, lyrical songs, dance songs, and instrumental music. But there are also various traditions of professional music. One of the oldest known traditions is the art of gusans. References to this tradition date back to sources from the fifth century. The tradition included narrators, singers, instrumentalists, dancers, and actors. Gusans were professionals performing to an audience and this art was handed on from a master to his disciples. In the seventeenth and eighteenth centuries, the art of ashugh that spread across Armenia shared some features of the art of gusans; however, there were certain differences in the form and content of their music as well as in their performance traditions. The name ashugh appears in many languages and comes from Arabic, meaning 'in love' (Pahlevanyan \& Kerovpyan \& Sarkisyan 2001). Ashugh art was largely based on the poetic formulas of Middle Eastern literature: it had much in common with the system of melodic modes used in Middle Eastern traditional music, i.e. Azeri mughams, and Persian and Arabian maqams, and it was often performed to the same audience (Kushnaryov 1958: 240-258; Pahlevanyan 2005: 33-34; Atayan 1965: 26-52). Ashugh art was both close and important to Brutyan, who lived in the ashugh centre of the nineteenth-century Alexandropol, and collected many ashugh songs (Brutyan 1985: 15-17). Komitas, on the other hand, according to the common narrative in Armenian musicological discourse, did not consider ashugh art to 
be 'true' Armenian music as it was strongly influenced by Middle Eastern art (Shaverdyan 1989: 106-107).

As for its structural features, Armenian music is firmly rooted in the traditions of the Middle East. Both secular and medieval religious music are monodic traditions. The scales are not based on dividing the octave and repeating the intervallic structure an octave higher or lower. In Middle Eastern and Caucasian music, vibrato, glissando, and tremolo are widespread and concern a different intonation of certain scale steps. Among Armenian singers, the most common ambit for vibrato are whole tone, semitone, or less. Vibratos with the ambit of third and sometimes fourth resembling tremolo also appear, but less frequently. However, these are common phenomena in Islamic musical culture and occur in the music of Armenian ashughs (Pahlevanyan 2005: 33-34), whose art crossed the borders of various states and empires. The rhythm in Armenian music is additive and rhythmic patterns of irregular duration follow each other, contrasting against the divisive rhythmic thinking in which a larger period of time is divided into smaller rhythmic units (Sachs 1953: 25).

While describing Armenian music, musicologists often use theoretical tools that are unambiguously associated with Western culture, which is very different from the culture of the Caucasus and the Middle East. Such an approach, which was particularly widespread before the era of sound recording, is problematic. Armenian traditional music has developed in the Middle Eastern sphere of culture, and contains phenomena that are structurally very different from Western classical music. For example, while describing the pitch structures of Armenian traditional music, all leading Armenian musicologists refer to its modal, diatonic structure. ${ }^{17}$ However, European modal scales have nothing to do with Armenian music, as they go back to the medieval church modes and belong to the European pitch structuring system. Later, during the height of national romanticism, they were performed on equal-tempered instruments.

Armenians are certainly not the only nation to apply the concept of diatonic scales when it comes to describing their traditional music. This was and still is a common practice in many countries in Eastern Europe, something that started in the nineteenth century, when Ukrainian researcher Sokalsky aimed to set all traditional music within the frames of Greek diatonic tetrachords (Spencer 2001: 625-626). In the atmosphere of national awakening, several structural features of the folk music (and poetry) of small nations were used to prove their origin in ancient civilisations and their honourably long history. The use of diatonic scales for describing different types of folk music and linking them with ancient European musical cultures stimulated national pride (Ambrazevičius 2006; Lippus 1988: 89, 91). This approach seems to apply also to the historical development of the theory of Armenian traditional music. The 
founder of this theory in Armenian music was again Komitas (Brutyan 1973: 226-228; Kushnaryov 1958: 11). This was one more of his many contributions to the European discourse in Armenian music theory.

There are also cognitive reasons that make descriptions of pitch structures in Armenian traditional music by projecting them on the diatonic scales unsuitable. The musical perception of many researchers, brought up in the Western tradition, often performs this transfer unconsciously when trying to analyse music in an unknown tuning system. Therefore, sometimes, analysis may rather blend the structure of music that it should explain, which was especially the case during the early folklore movement. It seems to be the case with Armenian music as well. Diatonic octave modes are applied in the analysis of melodies that use only part of the scale steps. However, several modes contain similar tetrachords, pentachords, and even hexachords, not to mention trichordal melodies. Also, problems occur when a song contains more than seven scale steps of a diatonic octave-mode (either with smaller intervals or different intervallic structures of scale segments). Twentieth-century researchers understood that diatonic scales did not offer enough opportunities for describing this repertoire. However, for example, musicologist Margarit Brutyan has proposed that in order to describe Armenian traditional music we have to form new scales by combining different diatonic octave-modes (Brutyan 1973: 231-233). Nevertheless, this method seems to make their usage for analysing Armenian traditional music even more disputable.

\section{A COMPARATIVE ANALYSIS OF THE TRANSCRIPTIONS OF THE FOLK TUNE CHEM CHEM}

This song is a dance song and we have three transcriptions of it, all made in Limondjian system. ${ }^{18}$ One version is by Komitas (Fig. 1) and two more are by Brutyan (Figs. 2 and 3). The lyrics are approximately the same in all three versions. The melody of Chem chem consists of two lines, both begin and end with $\mathrm{C}$ (in one transcription Brutyan has presented $\mathrm{C}$ in the first two bar as a lower appoggiatura to D-flat). The final segments of the lines are similar but initial segments contrast: at the beginning of the first line of the melody, a motive is repeated, 'twisting' around the initial $\mathrm{C}$ (the whole scale is (G)-AB-flat-C-D-flat-E-F), ${ }^{19}$ while at the beginning of the second line, the melody ascends from $\mathrm{C}$ to $\mathrm{F}$, bringing in the 'oriental' gap - an augmented second or minor third (D-flat-E) - which is described in terms of the European system of diatonic modes. In the transcriptions this characteristic element of the melody is presented differently: in Komitas's transcription the movement (D-flat-E) 


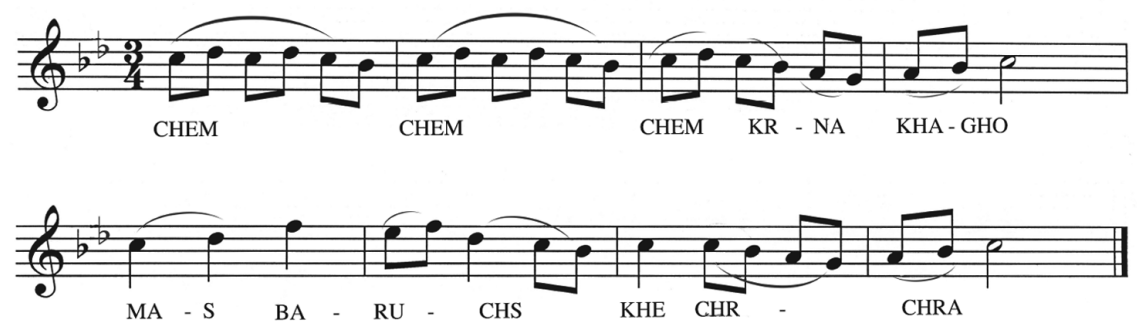

Figure 1. Chem chem by Komitas.

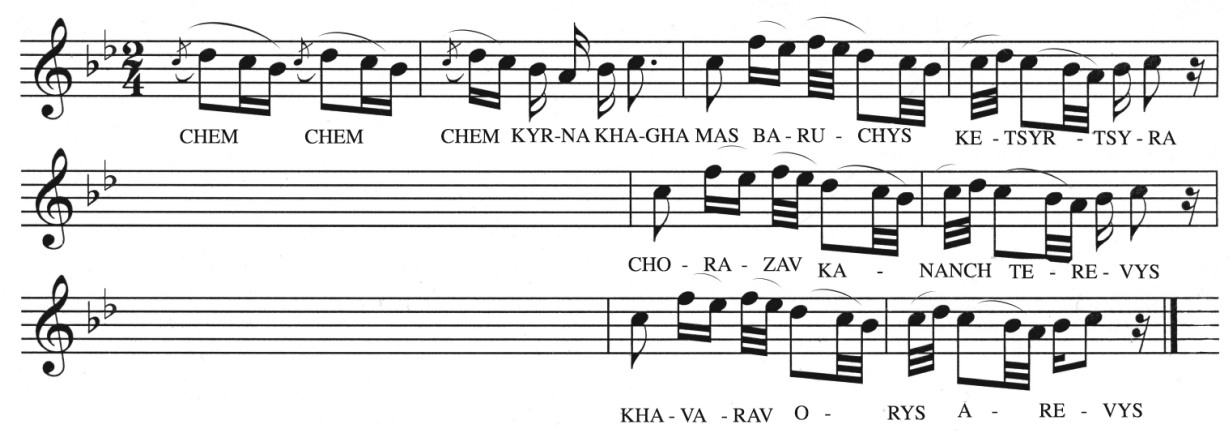

Figure 2. 1st version of Chem chem by Arshak Brutyan.
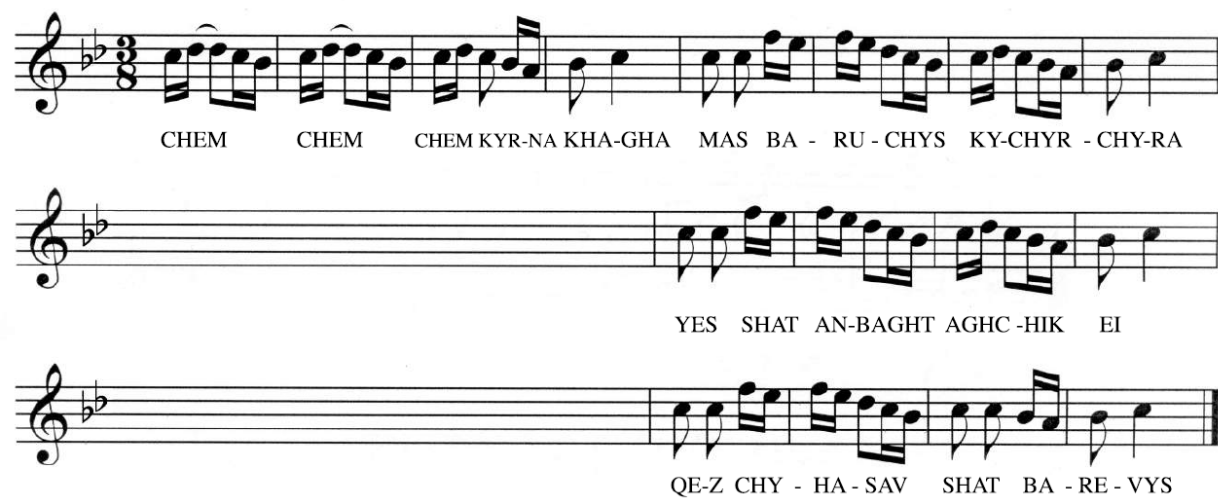

Figure 3. 2nd version of Chem chem by Arshak Brutyan. 
does not occur as a melodic interval between two consequent tones, while in Brutyan's, as we see below, that is much more prominent.

More remarkable differences between the transcriptions occur in the notation of rhythm. Armenian monodic music is melismatic and rhythms are irregular (Pahlevanyan \& Kerovpyan \& Sarkisyan 2001), and in Komitas's transcription this aspect is clearly smoothed, resulting in a rather simple melody in $3 / 4$ time with relatively homogeneous movement. It is difficult to distinguish the embellishing tones from structurally more important ones. In stressed positions - such as the beginning of a bar or a beat, or a long note - the tone $\mathrm{C}$ prevails. Both melody lines contain four bars, just as in the structure of a classical period. As for the tonal structure, balance and completeness are not very strong, but certain developmental characteristics can be found at the beginning of the second melody line containing a rise to the high fourth. Only seconds and thirds are used as melodic intervals, although in the sixth bar this 'oriental' gap is noticeable between structurally important tones, but it does not occur directly in the melody.

Another important difference in Komitas's transcription as compared to Brutyan's is G in the final segment of both melody lines; thereby the melody in his transcription covers almost the whole octave span, confirming the impression that also tonal structure is 'adapted' to the western tradition. In this way, it would be easy to harmonise the melody and transpose it into different tonalities. This, in fact, was done by Komitas in his compilation of solo songs where the song was in G minor (Komitas 1960: 75-76). Of course, while singing or playing only the melody, it is possible to use this transcription as a scheme and perform rhythms as well as pitches more freely, so that a performer knowing the tradition would certainly be able to 'transform' the melody back to Armenian tradition.

Brutyan's transcriptions are rhythmically more diverse. He has transcribed one version of Chem chem in duple and the other in triple time (2/4 and 3/8). In both cases the eighth note is the basic time unit. It is quite common in Armenian folk music for the same melody to be used for dances with different time signature (Atayan 1965: 33-34). Regardless of the time signatures, the way Brutyan has transcribed rhythmic figures does not leave one with the impression of strict metrical thinking. When comparing the two transcriptions by Brutyan, one can easily imagine that it would have been possible to transcribe the two initial syllable figures in the same way: in both cases $\mathrm{C}$ is a short note before a much longer D-flat, followed by quickly descending to B-flat. The same closeness can be observed through the melody. Hence, live performances might not have been so different from the visual notation; rather, they just did not fit very well with the European notation system. At the beginning of the twentieth century 
it was common for musicians-transcribers to consider the time-signature as something that was obligatory in notation, and they tried to convey the rhythms of various different traditions by means of using ever-changing signatures, ties, appoggiaturas, and various additional symbols to fit what they heard into the measures. In Brutyan's first (2/4) transcription, the visual image suggests stronger durational (structural) differentiation between the tones of the melody. Some notes are clearly embellishments to the longer and central tone of the syllable figure. As mentioned previously, Brutyan's transcriptions do not contain descending to $\mathrm{G}$ at the end of both lines, so the melody's pitch range is narrower (A-B-flat-C-D-flat-E-F). The most important difference, however, occurs at the beginning of the second line. In both of Brutyan's transcriptions the 'oriental' gap occurs between consecutive tones (in the descending passage F-E-D-flat). Although E is structurally less important, the characteristic 'oriental' sound becomes more prominent than in the transcription by Komitas. Certainly, all singers performed the song in their own way; however, a comparative analysis leaves the impression that Brutyan tried to record the melismatic character of the melody and its specific intonations while Komitas adapted it more in line with European ideas of a song.

\section{A COMPARATIVE ANALYSIS OF THE SONG LE LE YAMAN}

There are again three transcriptions of this lyrical song, one by Komitas (Fig. 4) and two by Brutyan (Figs. 5 and 6), all made in Limondjian system. ${ }^{20}$ This time, Komitas has dropped the time signature and marked only structural divisions and repetitions with bar lines. The first section contains three melodic phrases that correspond to the structure of the stanza, while the second four and the second section are repeated, and therefore the form of the strophe is ABB. There are also repetitions in the phrases, with the three phrases of the first section containing two melodic motives, $\mathrm{ABB}$, and the four phrases of the second section bring in only one more melodic motive that is repeated like a tonal sequence (ac1c2c3), with the last link ending in the 'tonic' $G$ (we can think in terms of a natural $g$-minor or the dorian mode from $\mathrm{G}$, but the tone E-flat or $\mathrm{E}$ that would define the mode unambiguously is missing and the scale is G-A-B-flatC-D-F). Komitas has chosen longer rhythmic values than Brutyan, and the time signature is absent. This absence might have ideological meaning but in the context of Komitas's transcriptions it probably refers, with longer rhythmic values, to a slow and rhythmically-free performance in which the durations are vague and only long and short notes are clearly differentiated. 


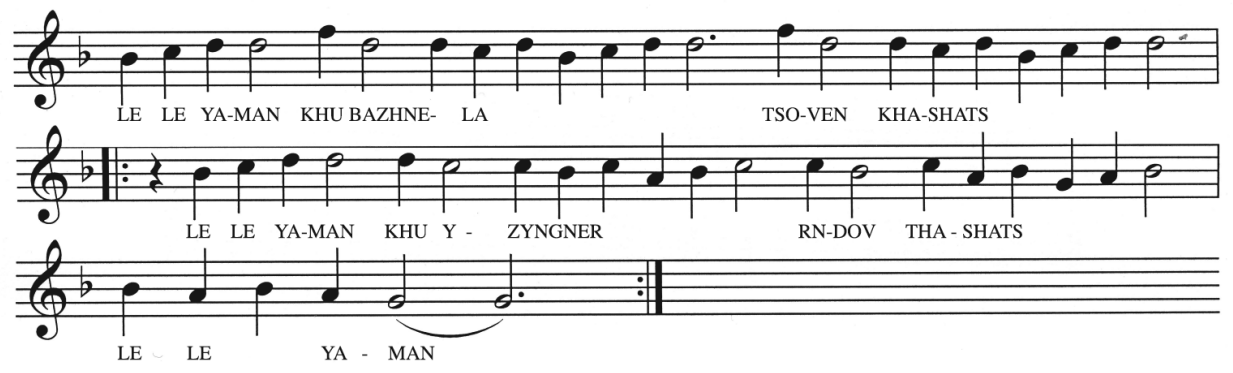

Figure 4. Le le yaman by Komitas.

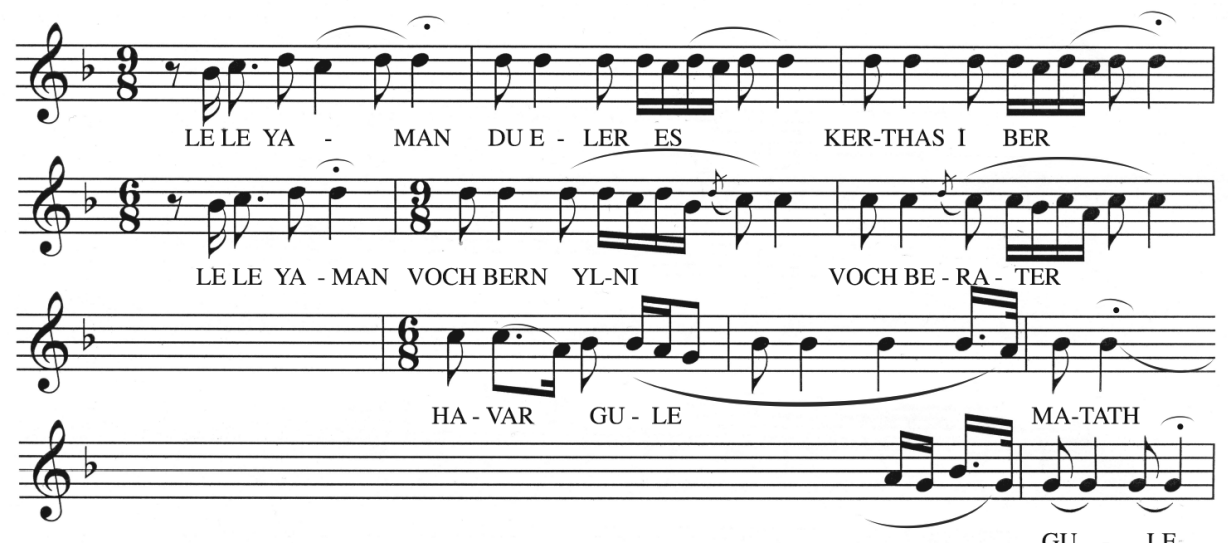

Figure 5. 1st version of Le le yaman by Arshak Brutyan.

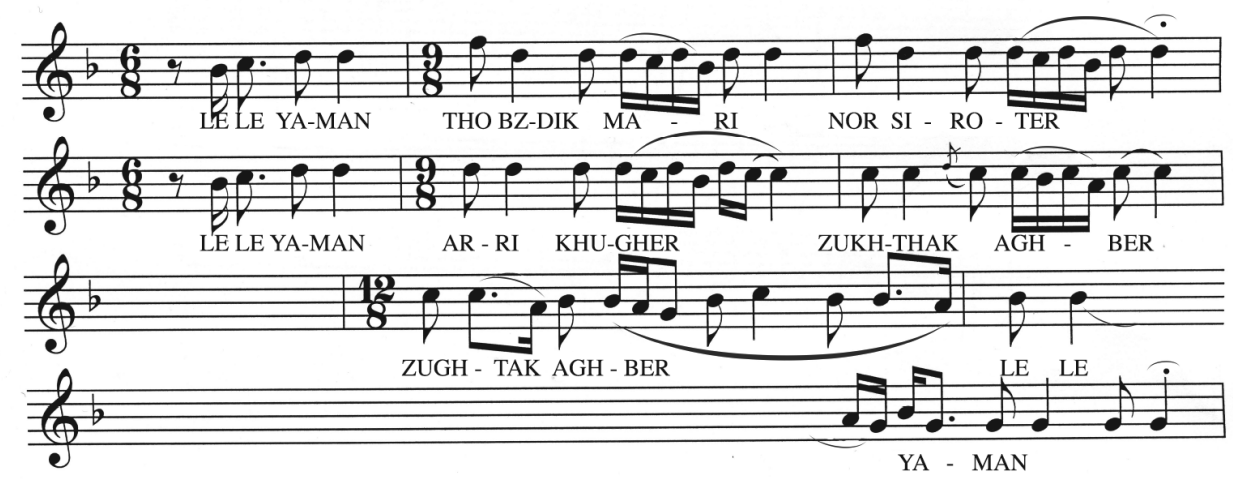

Figure 6. 2nd version of Le le yaman by Arshak Brutyan. 
Brutyan has preferred shorter note values, and has tried to record more nuances. In both transcriptions he has used the sixteenth, eighth, dotted eighth, and quarter notes, fermatas in some phrase endings, and once an appoggiatura and a tie. He has time signatures that constantly change. So his bar lines also mark structural divisions, but in this case using phrases (corresponding to the poetic lines), and not sections of the strophe.

What is more, Brutyan has recorded more small variations and embellishments in the melody and it does not seem so repetitive (schematic) as Komitas's transcription, although structural repetitions are the same. Quite an essential difference between Brutyan's own transcriptions is the lack of F in the first version, with the result that the tonal range of the melody is only fifth (G-A-B-flat-C-D). In Brutyan's second version and in Komitas's transcription, $\mathrm{F}$ occurs in accented positions and is an important characteristic of the song as, due to the lack of E-flat or E, the 'oriental' gap in the scale compares with the European diatonic modes.

\section{CONCLUSION}

The aim of this article was to show how transcriptions of folk tunes can reveal ideas about national identity in a much wider cultural context.

The transcriptions of the songs that have been compared were very similar in many aspects, considering their formal and tonal structure. Evidently, to some extent, both folklorists relied on the same theoretical framework. For example, as was typical of the period, most of their notations were in G (Brutyan 1985: 18) and they used the Limondjian system. At the same time, there were remarkable and systematic differences in the transcriptions of rhythmical figures, metric (or non-metric) structures, and melodic figuration.

In Komitas's transcriptions the rhythmic patterns are simpler. It seems that he used schematised rhythms as if they were a more universal solution. Brutyan, on the other hand, seems to have tried to record the rhythmic thinking inherent in an Eastern culture in the Western notation as accurately as possible. Noteworthy differences can also be noticed concerning Komitas's and Brutyan's melodic thinking. The first, for example, is characterised by adjusting modes, 'masking' the supposed augmented second, etc. Hereby, one has to emphasise that the tendencies described above can also be seen in other transcriptions made by Komitas and Brutyan. While comparing transcriptions by both of them with live music, Brutyan's transcriptions seem more relevant. This way, an impression forms that there are so many differences in transcriptions not 
because the songs were transcribed in different times and places but rather because of the priorities and personal choices made by folklorists.

As was said before, Komitas did not consider ashugh art to be 'real' Armenian music as it was strongly influenced by Middle Eastern art (Shaverdyan 1989: 106-107). The influences of European musical thinking can also be traced in the sound recordings: in 1912, he and his pupil, Spiridon Melikyan, were recorded performing folk tunes that they had collected. When compared to the recordings of traditional musicians, the intonations of Western classical music can clearly be heard. ${ }^{21}$

In contrast to Komitas, Brutyan did not work only with folk tunes, but transcribed much ashugh art music, and today this is considered to be his major contribution to Armenian musicology (Brutyan 1985: 17). Also, his transcriptions of simple folk melodies seem rather complex and often remind one of ashugh art. Unlike Komitas, Brutyan did not travel in the cultural centres of the West, but spent most of his life in Alexandropol, the centre of the ashugh community in the nineteenth century, and the famous ashughs, Jivani and Sheram, often performed at his concerts (ibid.: 15). One can only guess how much those circumstances influenced what he valued in folk music while making the transcriptions.

Today, Komitas's folk tune transcriptions are used as an authoritative source of traditional music. ${ }^{22}$ Indeed, they provide a good source of information for someone who knows the tradition. However, in Armenian traditional music we meet a blending of different cultures as this was a liminal space of various high cultures: Middle Eastern monody, European classical music, and traditional Armenian church singing. For that reason, the transcriptions from the nineteenth century should be approached carefully, as a comparison to recorded and living performances reveals that transcribers have 'corrected' the tunes, adapting them to the Western European system.

\section{NOTES}

1 For example, according to Geodakyan, Komitas foresaw "his mission already in his youth, and moved towards it, obstinately and stubbornly" (S iunosheskikh let on slovno predugadal svoe predznaznachenie i otnyne shel k izbrannoi tseli priamo i uporno) (Geodakyan 1969: 48).

${ }^{2}$ Ashughs - Middle Eastern minstrels who were narrators, singers, instrumentalists, dancers, and actors in one.

3 Komitas: The Complete Works, vol. 9-13 (1999-2004); Etnograficheskii sbornik, Armianskie narodnye pesni $i$ pliaski, tom 2 (Ethnographic collection, Armenian folk 
songs and dances, vol. 2) (1950); Armianskie narodnye pesni, etnograficheskii sbornik (Armenian folk songs, ethnographic collection) (1931).

4 Brutyan, Arshak 1985. Ramkakan Mrmunjner (Peasant Songs). Yerevan: Sovetakan groh.

5 Gevonyan, Armenuhi: Taronizhoghourdakan yergery (Folk songs of Taron region)(1978); Toumajian, Mihran: Armenian Folk Songs 4 (2005); Melikyan, Spiridon: Armianskie narodnye pesni $i$ pliaski 1 (Armenian folk songs and dances 1) (1949), Armianskie narodnye pesni i pliaski 2 (Armenian folk songs and dances 2) (1952); Muradyan, Hayrik: Rodnye pesni (Native songs) (1980); Toumajian, Mihran: Armianskie narodnye pesni 2 (Armenian folk songs 2) (1983), Armianskie narodnye pesni 3 (Armenian folk songs and dances 3) (1986).

${ }^{6}$ Pahlevanyan, Alina: Talin: Zhoghourdakan yergery [Talin: Folk Tunes] (1984). Yerevan: Sovetakan groh.

7 Hayrik Muradyan. Musical Relics of Armenia. CD. Recorded in Armenia from 1958 to 1988. Digitally remastered by ADD. Sondex, 2000.

${ }^{8}$ Live performance by Margarit Voskanyan, four sessions on 12-14 January 2013.

9 For such approaches see, for example, Levon Abrahamyan's Armenia and Armenians between East and West (www.noravank.am/upload/pdf/260_en.pdf, last accessed on October 9,2015$)$. See also the analysis of this topic by political scientist Ronald Grigor Suny, Constructing Primordialism: Old Histories for New Nations (2001).

${ }^{10}$ In the original: "[---] zhiznennyi put' Komitasa otrazhaet ne tol'ko i ne stol'ko ego lichnuiu sud'bu, skol'ko sud'bu vsego armianskogo naroda".

${ }^{11}$ In the original: "V samom sud'be Komitasa, ego zhiznennom puti, ternistom i tragicheskom, otrazilas' tselaia epokha istorii armianskogo naroda. Vremia pod"ema natsional'nogo samosoznaniia, bor'by, rozhdavshikhsia nadezhd i vremia sversheniia uzhasnoi tragedii 1915 goda, zatmivshei samye strashnye stranitsy mnogostradal'noi armianskoi istorii. Komitas do kontsa ispil gor'kuiu chashu stradanii, vypavshikh na doliu ego naroda."

12 See, for example, Geodakyan 1969, Shaverdyan 1989, Pahlevanyan \& Kerovpyan \& Sarkisyan 2001.

13 This, in fact, reflects broader changes: according to Smith, there was a clear division between a Western-orientated, more liberal Armenian nationalism emanating from the diaspora in Istanbul, Vienna, and Paris, and an Eastern-orientated revolutionary nationalism which owed more to Russian populism and German thought (Smith 2010: 12).

${ }^{14}$ For example, Toumajian, Mihran: Armianskie narodnye pesni 4 (Armenian Folk Songs 4) (2005); Melikyan, Spiridon: Armianskie narodnye pesni i pliaski 1 (Armenian folk songs and dances 1) (1949) and Armianskie narodnye pesni i pliaski 2 (Armenian folk songs and dances 2) (1952); Toumajian, Mihran: Armianskie narodnye pesni 2 (Armenian folk songs 2) (1983) and Armianskie narodnye pesni 3 (Armenian folk songs 3) (1986). 
${ }^{15}$ There were some differences in intoning the scale steps vernaghagh ( $e$ in Western notation) and nerknaghagh ( $a$ in Western notation).

${ }^{16}$ See, for example, Geodakyan 1969: pp. 84-85.

${ }^{17}$ See, for example, Brutyan 1973: 226-229; Pahlevanyan 2002: 10.

${ }^{18}$ Transcriptions into the European system were made by the author.

${ }^{19} \mathrm{G}$ occurs only in Komitas's version.

20 Transcriptions into the European system were made by the author.

${ }^{21}$ The Voice of Komitas Vardapet (CD). Recorded in Paris, 1912, digitally remastered by Anima Vox. OCTA Records Co Ltd., 1994.

${ }^{22}$ See, for example, the Grove Dictionary of Music and Musicians.

\section{ARCHIVAL MATERIALS}

House-Museum of Charents in Yerevan: Chem chem Komitas, fund 302, No. 131; Chem chem Brutyan, fund 4, No. 136; Le le jaman Komitas, fund 302, No. 135; Le le jaman Brutyan, fund 3, No. 31 .

\section{REFERENCES}

Adalian, Rouben Paul 2010. Historical Dictionary of Armenia. Lanham, Maryland: Scarecrow Press.

Anderson, Benedict 2006. Imagined Communities. London \& New York: Verso.

Atayan 1965 = Ataian, Robert. Armianskaia narodnaia pesnia. [Armenian Folk Songs.] Moskva: Muzyka.

Atayan 1973 = Ataian, Robert. Armianskaia srednevekovaia notopis'. [Armenian Medieval Notation System.] In: V. Vinogradov (ed.) Muzyka narodov Azii i Afriki. [Music of Asian and African Nations.] Moskva: Sovetskii kompozitor, pp. 168-186.

Bhabha, Homi K. 1994. The Location of Culture. London \& New York: Routledge.

Bohlman, Philip V. 2001 [1999]. Ontologies of Music. In: Nicholas Cook \& Mark Everist (eds.) Rethinking Music. New York: Oxford University Press, pp. 17-34.

Brutyan, Arshak 1985. Ramkakan Mrmunjner. [Peasant Songs.] Erevan: Sovetakan grokh.

Brutyan, Margarit 1973. Ladovaya sistema armyanskoy narodnoy (krest'yanskoy) muzyki. [Modal System of Armenian Traditional (Peasant) Music.] In: I. Zemtsovskiy (ed.) Problemy muzykal'nogo fol'klora narodov SSSR. [Problems of Music Folklore of the Nations of the Soviet Union.] Moskva: Muzyka, pp. 226-238. 
Dahlhaus, Carl 1983 [1980]. Between Romanticism and Modernism: Four Studies in the Music of the Later Nineteenth Century. Berkeley \& Los Angeles: University of California Press.

Davis, Aeron 2008. Investigating Cultural Producers. In: M. Pickering (ed.) Research Methods for Cultural Studies. Edinburgh: Edinburgh University Press, pp. 53-67.

Geodakyan 1969 = Geodakian, Georgii. Komitas. [Komitas.] Erevan: Izd. AN ASSR.

Gevonyan, Armenuhi 1978. Taroni zhohovrdakan yergery. [Folk songs of Taron region.] Erevan: Sovetakan grokh.

Komitas 1931. Narodnye pesni: Etnograficheskii sbornik. [Armenian Folk Songs: Ethnographic Collection.] Erevan: Muz. sektor gos. izdatel'stva SSR Armenii.

Komitas 1950. Etnograficheskii sbornik, t. 2: Armianskie narodnye pesni i pliaski. [Ethnographic Collection, Volume 2: Armenian Folk Songs and Dances.] Erevan: Arm. Gos. izdat.

Komitas 1960. Sobranie sochinenii, T. 1: Sol'nye pesni i duety s soprovozhdeniem fortepiano. [Collected Works, Volume 1: Solo Songs and Duets to the Accompaniment of Piano.] Erevan: Armgosizdat.

Komitas 1999. The Complete Works, Volume Nine: Musical-Etnographic Heritage. Armenian Folk Songs, Book 1. Edited by R. Atayan. Erevan: Gitutyun. Available at http://serials.flib.sci.am/openreader/Hay\%20jox.erg.-1999/book/Binder1.pdf, last accessed on November 19, 2015.

Komitas 2000. The Complete Works, Volume Ten: Musical-Ethnographic Heritage. Armenian Folk Songs, Book 2. Edited by R. Atayan. Erevan: Gitutyun.

Komitas 2000. The Complete Works, Volume Eleven: Musical-Ethnographic Heritage. Armenian Folk Songs, Book 3. Edited by R. Atayan \& G. Gyodakyan. Erevan: Gitutyun.

Komitas 2003. The Complete Works, Volume Twelve: Musical-Ethnographic Heritage. Armenian Folk Songs, Book 4. Ethnographic edition. Edited by R. Atayan \& G. Gyodakyan. Erevan: Gitutyun. Available at http://serials.flib.sci.am/ openreader/Hay\%20jox.\%20erg.-2003/book/Binder1.pdf, last accessed on November 19, 2015.

Komitas 2004. The Complete Works, Volume Thirteen: Musical-Ethnographic Heritage. Armenian Folk Songs. Modal collection, facsimile edition. Edited by R. Atayan \& G. Gyodakyan. Erevan: Gitutyun. Available at http://serials.flib.sci.am/openreader/ Hay\%20jox.\%20erg.-2004/book/Binder1.pdf, last accessed on November 19, 2015.

Kushnaryov 1958 = Kushnarev, Khristofor. Voprosy istorii $i$ teorii armianskoi monodicheskoi muzyki. [Problems of History and Theory of Armenian Monodic Music.] Leningrad: Gosudarstvennoe muzykal'noe izdatel'stvo.

Lippus, Urve 1988. Regiviiside heliread. [The Scales of Runic Melodies.] In: U. Lippus (comp.) Muusikalisi lehekülgi 5. Tallinn: Eesti Raamat, pp. 88-130.

Melikyan 1949 = Melikian, Spiridon. Armianskie narodnye pesni i pliaski 1. [Armenian Folk Songs and Dances 1.] Erevan: Armgiz.

Melikyan 1952 = Melikian, Spiridon. Armianskie narodnye pesni i pliaski 2. [Armenian Folk Songs and Dances 2.] Erevan: Aipetrat.

Muradyan 1980 = Muradian, Airik. Hayreni yergery. [Armenian Songs.] Erevan: Sovetakan grokh. 
Muradyan 1960 = Muradian, Matevos. Armianskoe sovetskoe muzykovedenie (kratkii obzor). [Armenian Soviet Musicology (Short Overview).] In: Robert Ataian \& Margarit Arutyunyan \& Georgi Budaghian (eds.) Muzyka sovetskoi Armenii: sbornik statei. [Music of Soviet Armenia: Collection of Articles.] Moskva: Gosudarstvennoe muzykal'noe izdatel'stvo, pp. 337-353.

Muradyan, Matevos \& Atayan, Robert \& Tatevosyan, Aleksandr 1956. Armianskie kompozitory. [Armenian Composers.] Erevan: Armianskoe gosudarstvennoe izdatel'stvo.

Nercessian, Andy 2000. A Look at the Emergence of the Concept of National Culture in Armenia: The Former Soviet Folk Ensemble. International Review of the Aesthetics and Sociology of Music, Vol. 31, No. 1, pp. 79-94. http://dx.doi.org/10.2307/3108426.

Pahlevanyan 1984 = Pakhlevanian, Alina. Talin: Zhoghovrdakan yergery. [Talin: Folk Tunes.] Erevan: Sovetakan grokh.

Pahlevanyan 2005 = Pakhlevanian, Alina. Voprosy armianskoi muzykal'noi fol'kloristiki . [Problems of Armenian Musical Folklore.] Erevan: Izd-vo EGK.

Panossian, Razmik 2002. The Past as Nation: Three Dimensions of Armenian Identity. Geopolitics, Vol. 7, No. 2, pp. 121-146. http://dx.doi.org/10.1080/714000931.

Pickering, Michael 2008. Experience and the Social World. In: M. Pickering (ed.) Research Methods for Cultural Studies. Edinburgh: Edinburgh University Press, pp. 17-31.

Poladian, Sirvart 1972. Komitas Vardapet and His Contribution to Ethnomusicology. Ethnomusicology, Vol. 16, No. 1, pp. 82-97. http://dx.doi.org/10.2307/850444.

Sachs, Curt 1953. Rhythm and Tempo: A Study in Music History. New York: W.W. Norton \& Company Inc.

Shaverdyan 1989 = Shaverdian, Aleksandr. Komitas. [Komitas.] Moskva: Sovetskii kompozitor.

Smith, Anthony D. 2010. Diasporas and Homelands in History: The Case of the Classic Diasporas. In: Allon Gal \& Athena S. Leoussi \& Anthony D. Smith (eds.) The Call of the Homeland: Diaspora Nationalisms, Past and Present. Leiden \& Boston: Brill, pp. 3-25.

Spencer, Jennifer 2001. Sokal's'ky Petro Petrovych. In: Stanley Sadie \& John Tyrrell (eds.) The New Grove Dictionary of Music and Musicians, 2nd edition. London: Macmillan Publishers Limited, pp. 625-626.

Suny, Ronald Grigor 2001. Constructing Primordialism: Old Histories for New Nations. The Journal of Modern History, Vol. 73, No. 4, pp. 862-896. http://dx.doi. org/10.1086/340148.

Ter-Sarkisyants 2005 = Ter-Sarkisiants, Alla. Istoriia i kul'tura Armianskogo naroda . [History and Culture of Armenian Nation.] Moskva: Vostochnaia literatura RAN.

Tololyan, Khachig 2005. Armenian Diaspora. In: Melvin Ember \& Carol R. Ember \& Ian Skoggard (eds.) Encyclopedia of Diasporas: Immigrant and Refugee Cultures Around the World. Volume I: Overviews and Topics. Berlin: Springer, pp. 35-46. Toumajian, Mihran 1983. Armianskie narodnye pesni 2. [Armenian Folk Songs 2.] Erevan: AN Armianskoi SSR.

Toumajian, Mihran 1986. Armianskie narodnye pesni 3. [Armenian Folk Songs 3.] Erevan: AN Armianskoi SSR.

Toumajian, Mihran 2005. Armianskie narodnye pesni 4. [Armenian Folk Songs 4.] Erevan: AN Armianskoi SSR. 
Turino, Thomas \& Lea, James (eds.) 2004. Identity and the Arts in Diaspora Communities. Warren, Michican: Harmonie Park Press.

Wodak, Ruth \& De Cillia, Rudolf \& Reisigl, Martin \& Liebhart, Karin 1999. The Discursive Construction of National Identity. Edinburgh: Edinburgh University Press.

Yazedjian, Ani 2004. Reconstructing the Armenian: The Genocide as a Cultural Marker in the Reification of Armenian Identity. In: Thomas Turino \& James Lea (ed.) Identity and the Arts in Diaspora Communities. Warren, Michigan: Harmonie Park Press, pp. 39-50.

\section{ONLINE SOURCES}

Ambrazevičius, Rytis 2006. Pseudo-Greek Modes in Traditional Music as Result of Misperception. 9th International Conference on Music Perception and Cognition, pp. 1817-1822. Available at http://www.researchgate.net/publication/228842690_ Pseudo-Greek_modes_in_traditional_music_as_result_of_misperception, last accessed on November 19, 2015.

Pahlevanyan, Alina \& Kerovpyan, Aram \& Sarkisyan, Svetlana 2001. Armenia. The New Grove Dictionary of Music and Musicians. Available at http://www. oxfordmusiconline.com:80/subscriber/article/grove/music/42078, last accessed on October 9, 2015.

Samuelian, Thomas J. \& Hajian, Aram \& Martirossian, Hakob \& Hajian, Tamar 2003. Armenia2020: Diaspora-Homeland Issue Paper prepared by the Arak-29 Foundation (Yerevan). Available at http://citeseerx.ist.psu.edu/viewdoc/downlo ad?doi=10.1.1.468.6733\&rep=rep1\&type=pdf, last accessed on October 9, 2015.

\section{RECORDINGS}

The Voice of Komitas Vardapet (CD) 1994. Recorded in Paris, 1912, digitally remarstered by Anima Vox. OCTA Records Co. Ltd.

Muradyan, Hayrik 2000. Musical Relics of Armenia (CD). Recorded in Armenia, 19581988, digitally remastered by ADD. Sondex. 